\title{
Corticosteroid associated lupus pancreatitis
}

Semra Demirli Atıcl

(iD) Ömer Engin ${ }^{1}$

(iD) Göksever Akpınar ${ }^{1}$

(iD) Cem Tuğmen ${ }^{1}$

1. University of Health Sciences, Tepecik Training and Research Hospital, Department of General Surgery, İzmir, Turkey.

http://dx.doi.org/10.1590/1806-9282.66.10.1414

\section{SUMMARY}

The relationship between acute pancreatitis and the administration of glucocorticoids is unclear because most reported cases have been diagnosed with systemic vascular diseases, such as systemic lupus erythematosus, which may be responsible for pancreatitis.

A 22-year-old woman with eye involvement of a newly diagnosed systemic lupus erythematosus was admitted to our hospital. Pulse intravenous methylprednisolone therapy was given at $1 \mathrm{mg} / \mathrm{kg}$ day for 3 days, and oral prednisolone at $40 \mathrm{mg} /$ day thereafter. During pulse steroid therapy, she had abdominal pain, back pain, distention, nausea, and vomiting. Her physical examination was compatible with acute abdomen and peritonitis. Abdomen Computerized Tomography scan revealed diffuse liquid perihepatic and perisplenic area with heterogeneity around the mesentery. Due to the symptoms of acute abdomen, explorative laparotomy was performed. There was diffuse free fluid in the abdomen and edematous changes were observed around the pancreas. Amylase and lipase from intraabdominal fluid were studied and found to be high. The postoperative prednol dose was reduced carefully. On the sixth postoperative day, the drain was removed, and the patient was discharged without any problem.

Physicians should keep in mind that acute pancreatitis may also be a cause of differential diagnosis of newly developed abdominal pain in patients receiving pulse steroid therapy with a normal level of serum amylase and lipase.

KEYWORDS: Lupus Erythematosus, Systemic. Pancreatitis. Pulse Therapy, Drug. Steroids.

\section{INTRODUCTION}

Systemic lupus erythematosus (SLE) is a chronic inflammatory disease that can affect any part of the gastrointestinal system, from the oral mucosa to the rectum ${ }^{1}$. Acute pancreatitis is an uncommon complication that occurs in $0.85 \%$ to $4 \%$ of patients with SLE and is reported to be a rare adverse reaction associated with the administration of corticosteroids ${ }^{2}$. The relationship between acute pancreatitis and administration of glucocorticoids is unclear because most reported cases have been diagnosed with systemic vascular diseases, such as systemic lupus erythematosus, which may be responsible for pancreatitis ${ }^{2}$.Here, we report a 22-year-old woman who developed acute pancreatitis after receiving steroid pulse therapy for the treatment of eye involvement in SLE.

\section{Case presentation}

A 22-year-old woman was admitted to our hospital because of eye and neurological involvement of newly diagnosed systemic lupus erythematosus. She had no gallstone on imaging methods and no history of hypertriglyceridemia and alcohol intake. She was given intravenous methylprednisolone pulse therapy at $1 \mathrm{mg} / \mathrm{kg}$ day for 3 days, and oral prednisolone at 40

DATE OF SUBMISSION: 23-Jan-2020

DATE OF ACCEPTANCE: 23-May-2020

CORRESPONDING AUTHOR: Semra Demirli Atici

Sağlık Bilimleri Üniversitesi Tepecik Eğitim ve Araştırma Hastanesi, Güney Mahallesi, 1140/1, Sokak n.1, Yenişehir Konak, İzmir, Turkey - 35180

Tel:+90 536 362-4585 / Fax: +90 232 433-0756

E-mail: smrdemirli@hotmail.com 
$\mathrm{mg} /$ day thereafter. During pulse steroid therapy she had abdominal pain, back pain, distention, nausea, and vomiting. Her physical examination was compatible with acute abdomen and peritonitis. The patient was consulted with general surgery. While her leucocytes increased rapidly (11.100x10/3/uL to $29.800 \times 10 \wedge 3 / \mathrm{uL})$, she started complaining of mild back pain with normal serum amylase (31U/L) and lipase levels (40U/L). Abdomen Computerized Tomography scan revealed diffuse liquid perihepatic and perisplenic area with heterogeneity around the mesentery (Figure 1). Due to the symptoms of acute abdomen, explorative laparotomy was performed. No perforation was detected during explorative laparotomy. There was diffuse free fluid in the abdomen and edematous changes were observed around the pancreas (Figure 2). Amylase and lipase from intra-abdominal fluid were studied and found to be higher (1190 U/L and $2040 \mathrm{U} / \mathrm{L})$. The abdomen was irrigated with plenty of saline solution and drains were placed. Although the blood amylase and lipase levels were normal in the preoperative laboratory tests, postoperative control tests were found to be high. The patients' preoperative albumin ratio, Complements C3 and C4 levels were low with an elevated anti-dsDNA. The postoperative prednol dose was reduced carefully. On the sixth postoperative day, the patient was discharged without any problems. The patient continues to use low-dose steroids in the postoperative $8^{\text {th }}$ month and is followed up without any problems.

\section{DISCUSSION AND CONCLUSION}

FIGURE 1. COMPUTERIZED TOMOGRAPHY SCAN OF THE ABDOMEN REVEALED DIFFUSE LIQUID PERIHEPATIC AND PERISPLENIC AREA WITH HETEROGENEITY AROUND THE MESENTERY

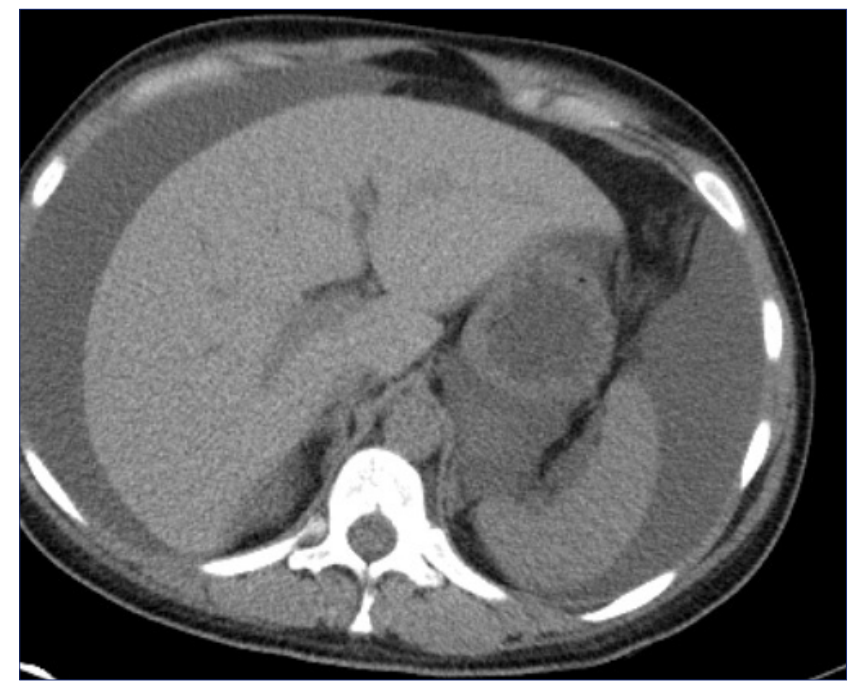

Acute pancreatitis is a rarely seen clinical entity among patients with SLE. Lupus associated pancreatitis (LAP) occurs within days to weeks of starting medium-to-high dose corticosteroids. Dwivedi et al have used the term 'corticosteroid-associated lupus pancreatitis' (CALP) the point at which it happened inside 3 weeks ${ }^{3}$.

CALP had a female predominance ${ }^{3}$. The most frequent symptom of CALP was abdominal pain, followed by vomiting, paralytic ileus, and fever, which generally present under the corticosteroid therapy ${ }^{3}$. Imaging methods such as ultrasound or computed tomography may be helpful for the diagnosis, with the appearance of the heterogeneous pancreas and peripancreatic fluid collection ${ }^{3}$.

The role of corticosteroids in the etiology of lupus pancreatitis is controversial and not clear. Animal studies have shown that corticosteroids can induce pancreatitis and are generally useful in the treatment of acute pancreatitis ${ }^{3,4}$. Although, multiple factors such as the activity of disease, gallstones, drugs, alcohol, and hypertriglyceridemia may play

FIGURE 2. THERE WAS DIFFUSE FREE FLUID IN THE ABDOMEN, AND EDEMATOUS CHANGES WERE OBSERVED AROUND THE PANCREAS

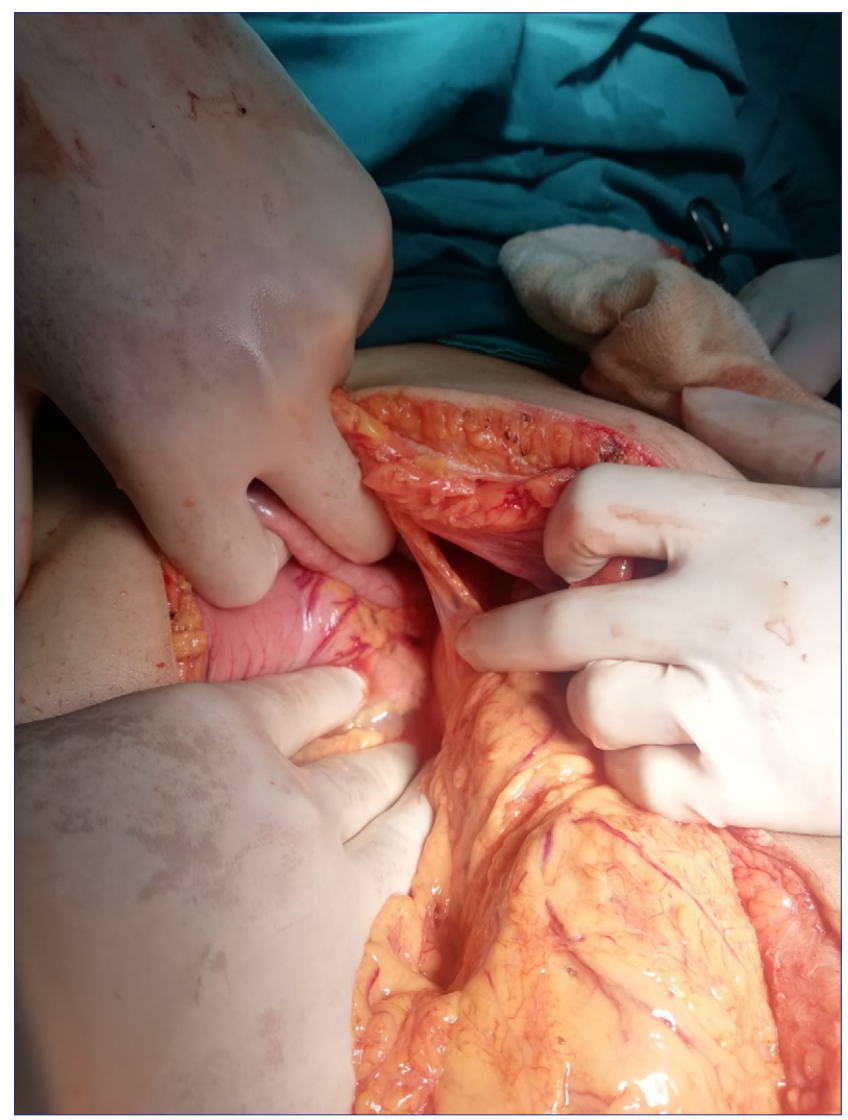


a role in the pathogenesis of pancreatitis with SLE ${ }^{1,2}$. In previous studies, high amylase and lipase levels were frequently found in patients associated with SLE pancreatitis ${ }^{3,4}$. To our knowledge, a case of CALP with normal preoperative lipase and amylase levels has not been reported as in our case.

As Dwivedi et al. ${ }^{3}$ reported after the occurrence of acute pancreatitis, for the treatment of CALP, corticosteroids were continued or a dose of corticosteroid was increased, such as our presented case. It is difficult to ascribe sole responsibility for pancreatitis to either disease activity or corticosteroids in these SLE patients ${ }^{3}$. The pathogenesis of pancreatitis in SLE is complex and difficult to relate to a single factor. It has been suggested that vasculitis, thrombosis secondary to antiphospholipid antibodies, vascular intimal thickening, and accumulation of immune complexes, as well as autoantibodies directly targeting the pancreas, may play a role in the etiology of cellular immune response ${ }^{3,4}$.

In conclusion, physicians should keep in mind that acute pancreatitis may also be a cause of differential diagnosis of newly developed abdominal pain in patients receiving pulse steroid therapy with a normal level of serum amylase and lipase. It's difficult to differentiate pancreatitis due to SLE or CALP. Due to the rarity of CALP, for a better understanding of the importance of etiopathogenesis, a larger case series may be better fitting.

\section{RESUMO}

A relação entre pancreatite aguda e a administração de glicocorticoides é incerta pois a maioria dos casos relatados foram diagnosticados com doenças vasculares sistêmicas, como lúpus eritematoso sistêmico, que pode causar pancreatite.

Uma paciente de 22 anos com envolvimento ocular e lúpus eritematoso sistêmico recém-diagnosticado foi admitida em nosso hospital. Pulsoterapia intravenosa com metilprednisolona $1 \mathrm{mg} / \mathrm{kg}$ foi administrada por 3 dias. Depois disso, a paciente foi tratada com prednisolona oral 40 mg/dia. Durante a pulsoterapia com corticoides, a paciente apresentava dor abdominal, dor nas costas, distensão, náusea e vômitos. O exame físico era compatível com quadro de abdome agudo e peritonite. Tomografia computadorizada do abdome revelou líquido difuso na região perihepática e periesplênica, com heterogeneidade ao redor do mesentério. Devido aos sintomas de abdome agudo, foi realizada laparotomia exploradora. Havia líquido livre difuso no abdome e alterações edematosas foram observadas em torno do pâncreas. A amilase e lipase do líquido intra-abdominal foram analisadas e consideradas elevadas. A dose pós-operatória de prednol foi reduzida com cuidado. No sexto dia de pós-operatório, o dreno foi retirado, e a paciente recebeu alta sem qualquer problema.

Médicos devem lembrar que a pancreatite aguda também pode ser uma causa de diagnóstico diferencial para dor abdominal recém-desenvolvida em pacientes recebendo pulsoterapia com corticoides e com níveis normais de amilase e lipase séricas.

Palavras Chave: Lúpus Eritematoso Sistêmico. Pancreatite. Pulsoterapia. Esteroides.

\section{REFERENCES}

1. Li Z, Xu D, Wang Z, Wang Y, Zhang S, Li M, et al. Gastrointestinal system involvement in systemic lupus erythematosus. Lupus. 2017;26(11):1127-38.

2. Gayam V, Mandal AK, Khalid M, Kaler J, Thapa S, Garlapati P, et al. A rare case of systemic lupus erythematosus with gastric ulcer and acute pancreatitis: a case report and literature review. Gastroenterology Res. 2018;11(4):321-5
3. Dwivedi P, Kumar RR, Dhooria A, Adarsh MB, Malhotra S, Kakkar N, et al. Corticosteroid-associated lupus pancreatitis: a case series and systematic review of the literature. Lupus. 2019;28(6):731-9.

4. Dong LH, Liu ZM, Wang SJ, Zhao S), Zhang D, Chen Y, et al. Corticosteroid therapy for severe acute pancreatitis: a meta-analysis of randomized, controlled trials. Int J Clin Exp Pathol. 2015;8(7):7654-60. 